\title{
Use of Steel and Polyolefin Fibres in the La Canda Tunnels: Applying MIVES for Assessing Sustainability Evaluation
}

\author{
Marcos G. Alberti ${ }^{1}$, Jaime C. Gálvez ${ }^{1, *(\mathbb{D}}$, Alejandro Enfedaque ${ }^{1}\left(\mathbb{O}\right.$, Ana Carmona ${ }^{2}$, \\ Cristina Valverde ${ }^{2}$ and Gabriel Pardo ${ }^{2}$ \\ 1 Departamento de Ingeniería Civil: Construcción, E.T.S de Ingenieros de Caminos, Canales y Puertos, \\ Universidad Politécnica de Madrid, c/Profesor Aranguren, s/n, 28040 Madrid, Spain; \\ marcos.garcia@upm.es (M.G.A.); alejandro.enfedaque@upm.es (A.E.) \\ 2 Sika S.A.U.Carretera de Fuencarral, 72, Alcobendas, 28108 Madrid, Spain; carmona.ana@es.sika.com (A.C.); \\ valverde.cristina@es.sika.com (C.V.); pardo.gabriel@es.sika.com (G.P.) \\ * Correspondence: jaime.galvez@upm.es; Tel.: +34-910-674-125
}

Received: 31 October 2018; Accepted: 7 December 2018; Published: 13 December 2018

check for updates

\begin{abstract}
Construction involves the use of significant quantities of raw materials and entails high-energy consumption. For the sake of choosing the most appropriate solution that considers environmental and sustainable concepts, tools such as the integrated value model for sustainable assessment (Modelo Integrado de Valor para una Evaluación Sostenible, MIVES) used in Spain, plays a key role in obtaining the best solution. MIVES is a multi-criteria decision-making method based on the value function concept and the seminars delivered by experts. Such tools, in order to show how they may work, require application to case studies. In this paper, two concrete slabs manufactured with differing reinforcements during the construction of the La Canda Tunnels are compared by means of MIVES. The two concrete slabs were reinforced with a conventional steel-mesh and with polyolefin fibres. This research was focussed on the main aspects affecting the construction. That is to say, the environmental, economic, and social factors were assessed by the method, being of special impact the issues related with maintenance of the structure. The results showed that from the point of view of sustainability, the use of polyolefin fibres provided a significant advantage, mainly due to the lower maintenance required.
\end{abstract}

Keywords: concrete sustainable evaluations; steel-mesh; polyolefin fibres

\section{Introduction}

Concrete, as is widely known, is manufactured by merging cement, aggregates, water, and in some cases, chemical additives. The diversity of cements since developed, and combinations of such cements with certain chemical additives have enabled numerous types of concretes to be manufactured that are suitable for a wide variety of uses. Based on the reduced cost of the concrete components, and their availability and adaptability, in the last century, it has become the most commonly used construction material. Hence, concrete structures for buildings and infrastructure can now be found across contemporary society. One reason for the success of concrete is that the total amount of cement consumed, which is mainly used as a raw material for concrete, has not stopped rising since the beginning of the 20th century. Moreover, the economic importance of cement consumption has reached such a point that it has been widely accepted as a parameter linked to the economic growth of countries [1]. Nevertheless, the cement production process is one of the main impacts of humankind on the environment, and it contributes to global warming, with 5-6\% of the total share 
of $\mathrm{CO}_{2}$ emissions [2]. However, there are ways to soften the impact of infrastructure construction, maintenance, and management on society and the environment alike.

One of the most commonly studied options entail incorporating by-products or waste materials as aggregates. Some authors claim that it is possible to develop a sustainable recycled concrete by incorporating ceramic waste as a coarse aggregate; they even consider the $\mathrm{CO}_{2}$ footprint and consumption volume of raw materials [3]. Others have sought to use waste from thermal power plants (marble aggregates, marble dust, and fly ash), as fillers in concretes for replacing natural aggregates, consequently reducing the impact on mountains, and extending the exploitation period of quarries [4]. Numerous factors, such as the mechanical properties of concrete with recycled aggregates [5], their long-term properties [6], the optimization of formulation by means of packing models [7], the effect of such type of aggregates in the fracture properties of concrete [8], or even the correct methodology for introducing recycled aggregates in the concrete formulation, have been studied $[9,10]$. In such a sense, recent research has also demonstrated that is possible to use the fine fraction of construction and demolition wastes, derived from prefabricated structures, as a substitution of natural fine aggregates for self-levelling mortars [11]. Not only recycling aggregates, but also other non-metallic wastes have been applied, in order to obtain artificial aggregates for lightweight concrete [12]. Moreover, even wastes from typical raw materials used for fibres, such as polyolefins, have also been successfully employed as aggregates for lightweight concrete [13], leading to what are considered as green building materials, especially focussed on non-structural applications.

Another way to reduce the environmental impact of infrastructure involves trying to soften the impact of cement production. Some researchers have done so by substituting or reducing the amount of cement used. There are studies that tried to change cement microstructure by using nanoparticles [14]. Another approach entails use of a by-product such as fly ash in high volumes as a way to obtain a sustainable product [15]. Similarly, waste glass powder has been another partial replacement of cement considered [16]. As can be seen, while this research field is blooming, these approaches have dealt only with the impact of the production of the constituents of concrete and the use of recycled aggregates, ignoring other aspects that are of importance.

Recently, a study of sustainability in the developed world has considered not only the economic point of view, but also the environmental perspective [17]. With such an approach, given that sustainability covers human activity in all its various forms, all associated advantages and disadvantages should be considered before taking any decision. If applied to civil engineering, it could involve infrastructure which (from a technical and economic point of view) could be beneficial. However, if its impact on society and the environment were considered, it would be discarded, due to an ensuing negative influence. One of the most effective ways to achieve sustainable solutions in the building industry is by designing and building durable infrastructure projects, with the goal of obtaining a long service life. Moreover, after finishing such a service life, the infrastructure still need to be demolished and transported to a landfill site where the debris produces a remarkable impact on the surrounding environment [18]. Following this rationale, the later the demolition of a structure occurs, the greater is the degree of sustainability of the infrastructure. The importance of the social, environmental, and economic costs that the construction phase, maintenance, refurbishment, and eventual demolition and transport to a landfill site, generate during the entire life cycle of the structure, can be determined by using multivariable methods.

Construction has a significant impact on the environment. It should be highlighted that around $40 \%$ of the total energy consumption in European Union corresponds to this sector, and civil works and building construction consume $60 \%$ of the raw materials that are extracted from the lithosphere [19]. The production, transport, and installation of materials such as steel, concrete, and glass require large amounts of energy. Nonetheless, this implies a minimal part of the cost of construction, which leads to new policies being required [20]. New solutions and materials could provide environmental benefits. The main objective of the present work is to apply a method, such as MIVES (Modelo Integrado de Valor para una Evaluación Sostenible), which permits multi-criteria methods to be used in the 
assessment of sustainability in a case study. In the mentioned application, the parameters chosen (as well as the life cycle and maintenance cost) play a major role in the decision-making process, and they change the optimum alternative from a conventional reinforced concrete option to another where reinforcement has been substituted by polymeric fibres.

\section{The Integrated Value Model for the Sustainable Assessment (MIVES) Method}

Tools such as the integrated value model for sustainable assessment (MIVES) are required to assess the sustainability of each construction alternative. Given that any construction project can be built with several alternatives, comparing such alternatives by the means of an index of sustainability that evaluates the whole life cycle of the structure is of significant interest.

MIVES combines the use of a discriminatory tree of requirements, the assignation of weights, and the use of value functions. This methodology involves defining the three previously mentioned aspects with several seminars of experts in the field. These seminars should provide accuracy and objectivity to the definition of the indicators, criteria, and requirements. The steps defined in reference [21] could be summarised in seven steps:

1. Define the problem

2. Produce a basic diagram

3. Establish the value functions

4. Define the relative weights

5. Define alternatives

6. Evaluate the alternatives

7. Decide on the optimum alternative

\section{Description of the Case Study in the La Canda Tunnels}

During the construction of the La Canda, two twin tunnels for the high-speed rail link that connects Madrid and Galicia, two concrete slabs were built at the same time. Both slabs were subjected to the same loads during their service life. However, one of them was reinforced with the conventional steel-mesh reinforcement, and the other was reinforced with polyolefin fibres. Therefore, a substitution of the conventional reinforcing bars was performed. This allowed an unadulterated comparison of the two solutions in terms of economic, environmental, and social impact, as all design and operative conditions were the same. That is to say, it provided an opportunity to assess sustainability by the means of MIVES. Figure 1 shows the visual aspect of the steel-mesh and the polyolefin fibres. The steel-mesh was made of B500S steel bars $(150 \times 150 \times 6 \mathrm{~mm})$, and the fibres were commercial fibres called SikaFibre T-48, which are available in the construction market.

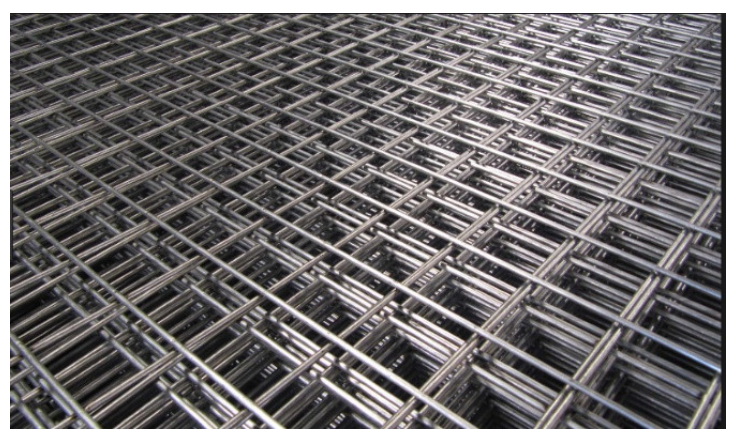

(a)

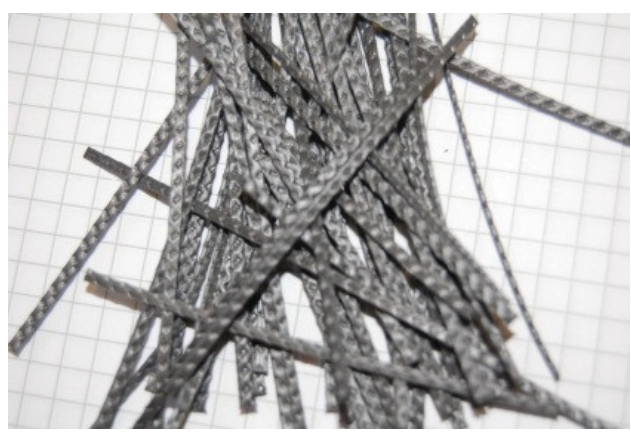

(b)

Figure 1. Visual aspect of the two different reinforcements: (a) steel mesh; (b) polyolefin fibres.

Given that the main differences were based on the reinforcement type, some of the parameters remained similar. That is to say, the use of the same quantity of cement or aggregates have null 
impact on the MIVES results. Conversely, those aspects in which fibres are used as a reinforcement imply important variations, such as maintenance of labour force, produce the main differences in the results of some of the indicators. The data related to the reinforced concrete (steel and synthetic fibres), dimensions, weight, reparation, and waste from the La Canda Tunnels case study were supplied by Sika as a contractor. Some specifications varied, given the variation of the reinforcement and the dimensions, and are shown in Table 1. The synthetic fibres were modelled based on data collected for the polypropylene fibres produced according to a standard polypropylene fibre production process. In this case, the synthetic fibres used were SikaFibre T48, which are produced in Spain. The Global Warming Potential (GWP) measures the potential contribution to climate change, focusing on emissions of greenhouse gases, such as carbon dioxide $\left(\mathrm{CO}_{2}\right)$, which enhance the heat radiation absorption of the atmosphere, causing the temperature at the earth's surface to rise; the values supplied can also be seen in Table 1. Regarding the mix design phase, the specifications for concrete were similar, with the same workability requirement (soft consistency), cement content, aggregates size, and quantities, as well as the required characteristic compressive strength of $25 \mathrm{MPa}$.

Table 1. Specifications considered for the two systems.

\begin{tabular}{ccc}
\hline & $\begin{array}{c}\text { Polyolefin Fibre-Reinforced } \\
\text { Concrete Slab }\end{array}$ & $\begin{array}{c}\text { Steel Mesh-Reinforced } \\
\text { Concrete Slab }\end{array}$ \\
\hline Dimension $(\mathrm{m})$ & $200 \times 50 \times 0.20$ & $200 \times 50 \times 0.20$ \\
Concrete type $[15]$ & $\mathrm{HA}-25 / \mathrm{B} / 20 / \mathrm{lI} \mathrm{Ha}$ & $\mathrm{HA}-25 / \mathrm{B} / 20 / \mathrm{II}$ \\
Reinforcement $\left(\mathrm{kg} / \mathrm{m}^{2}\right)$ & 0.80 & 3.11 \\
Global Warming Potential $\left(\mathrm{kg} \mathrm{CO}_{2}\right.$ eq) & 2.39 & 5.30 \\
\hline
\end{tabular}

One of the major variations is based on the costs of the slab maintenance. The appearance of both alternatives after three years of service can be seen in Figure 2. In this figure, it is easy to perceive that the conventional construction has suffered from a cracking process, while the polyolefin fibre-reinforced slab showed no hints of cracks. The construction and maintenance costs per square-metre can be seen in Table 2. The fibre-reinforced solution involved the same thickness, $0.20 \mathrm{~m}$, though the maintenance costs were remarkably lower than those of the steel-reinforced concrete.

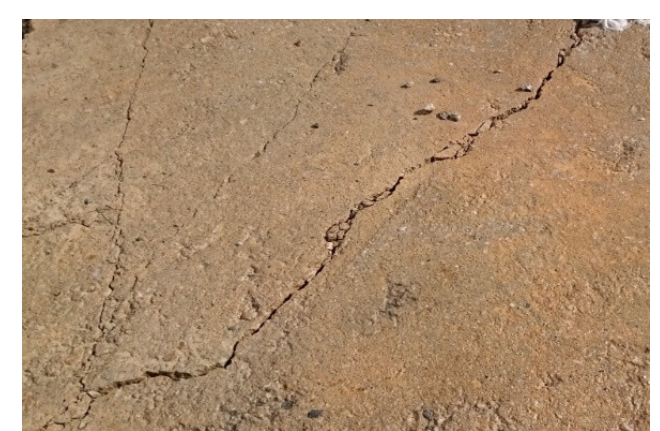

(a)

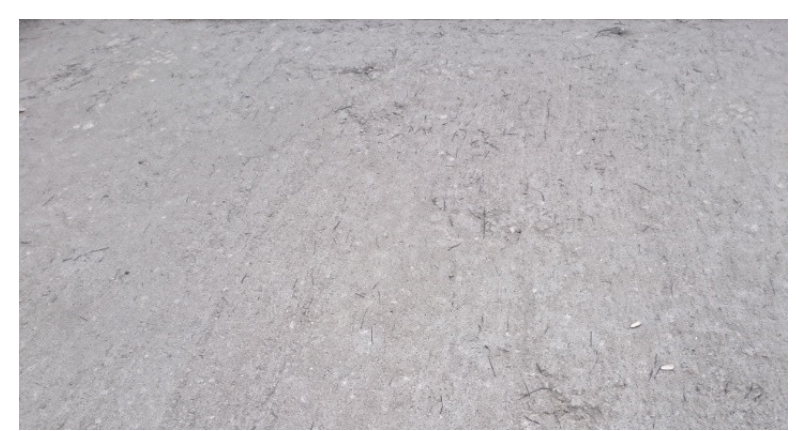

(b)

Figure 2. Visual aspect of the slabs after three years of service: (a) steel mesh reinforced concrete slab; (b) polyolefin fibre reinforced concrete slab. 
Table 2. Costs for one square-meter of reinforced concrete.

\begin{tabular}{cccc}
\hline & & $\begin{array}{c}\text { Polyolefin Fibre-Reinforced } \\
\text { Concrete Slab }\end{array}$ & $\begin{array}{c}\text { Steel Mesh-Reinforced } \\
\text { Concrete Slab }\end{array}$ \\
\hline \multirow{2}{*}{ Purchase cost $\left(€ / \mathrm{m}^{2}\right)$} & Reinforcement & 3.2 & 3 \\
& Concrete & 60 & 60 \\
\hline \multirow{2}{*}{ Maintenance cost $\left(€ / \mathrm{m}^{2}\right)$} & Reinforcement & 0 & 6 \\
& Labour & 0 & 348 \\
& Energy & 0 & 70 \\
\hline
\end{tabular}

\section{Results of the Application of MIVES}

The use of MIVES for the sustainability assessment in building and civil engineering applications was carefully described in reference [22]. Therefore, the economic, environmental, and social impacts have been assumed to be those stated in the reference. The indicators were adapted to this case, and increasing linear value functions were chosen in order to evaluate each criteria. The weights and the requirements tree, as well as the main criteria and the description of the indicators, can be seen in Table 3. In this table, it can be seen that the main values of weights of economic (50\%), environmental $(30 \%)$, and social $(20 \%)$ requirements were directly chosen as those of reference [22] in order not to modify the essence of the method, and to maintain reliable use.

The weights of the main criteria were adapted, considering that this study was focussed in a previously constructed structure that had had relevant issues during its service life. The criteria in terms of environmental requirements were mainly focussed on the material consumption and emissions, with an adaptation of the method that could consider the maintenance in a more visible scenario. Concerning the social criteria, health and safety were considered with the same weight as well as the affection to third parties.

The maximum, minimum, and slope of each criteria were chosen in a seminar given by the authors. The maximum of cement per square meter was fixed at $150 \mathrm{~kg} / \mathrm{m}^{2}$, and the minimum at $55 \mathrm{~kg} / \mathrm{m}^{2}$. The aggregates ranged from $240 \mathrm{~kg} / \mathrm{m}^{2}$ and $600 \mathrm{~kg} / \mathrm{m}^{2}$ and the water-to-cement ratio was considered between 0.3 and 0.8 . The data supplied assumed that $10 \%$ of the slab was being reconstructed every year, although it was considered for the method that $3 \%$ would be needed for such a period. Contrary to what Table 2 shows (compiled from the data supplied), in the method it was considered to be $10 \%$ of the steel-mesh reinforced concrete slab maintenance-cost in the polyolefin fibre-reinforced concrete slab.

The results of the application of the MIVES method to this case study can be seen in Table 4, which supplies the final and partial scores for each of the solutions. The score for the steel mesh-reinforced slab was 75, in contrast with a final score of 45 in the case of the slab made from polyolefin fibre-reinforced concrete. 
Table 3. Requirements tree and weights.

\begin{tabular}{|c|c|c|c|c|c|c|}
\hline REQUIREMENT & (R. Weights) & CRITERIA & (C. Weights) & INDICATORS & (I. Weights) & \\
\hline \multirow{4}{*}{ R1. Economic } & \multirow{4}{*}{$50 \%$} & C1 Total costs. Direct + Indirect & $40 \%$ & I1 Total costs including construction time & $100 \%$ & $100 \%$ \\
\hline & & C2 Quality & $10 \%$ & I2 Non-quality costs & $100 \%$ & $100 \%$ \\
\hline & & C3 Dismantling & $10 \%$ & I3 Dismantling costs & $100 \%$ & $100 \%$ \\
\hline & & C4 Service life & $40 \%$ & $\begin{array}{l}\text { I4 Cost of service, maintenance, energy, change of use } \\
\text { I5 Resilience. Risk of disaster } \times \text { cost of reconstruction }+ \text { lack of use }\end{array}$ & $\begin{array}{l}80 \% \\
20 \% \\
\end{array}$ & $100 \%$ \\
\hline \multirow{6}{*}{ R2. Environmental } & \multirow{6}{*}{$30 \%$} & & $100 \%$ & & & \\
\hline & & $\begin{array}{l}\text { C5 Material consumption at } \\
\text { construction time }\end{array}$ & $20 \%$ & $\begin{array}{l}\text { I6 Cement } \\
\text { I7 Aggregates } \\
\text { I8 Reinforcement (steel mesh, steel fibres, polyolefin fibres) } \\
\text { I9 Water } \\
\text { I10 Auxiliary materials } \\
\text { I11 Reused materials }\end{array}$ & $\begin{array}{l}25 \% \\
10 \% \\
15 \% \\
25 \% \\
15 \% \\
10 \% \\
\end{array}$ & $100 \%$ \\
\hline & & $\begin{array}{l}\text { C5 Material consumption for } \\
\text { maintenance }\end{array}$ & $20 \%$ & $\begin{array}{l}\text { I6 Cement } \\
\text { I7 Aggregates } \\
\text { I8 Reinforcement (steel mesh, steel fibres and polyolefin fibres) } \\
\text { I9 Water } \\
\text { I10 P auxiliary materials } \\
\text { I11 Reused material }\end{array}$ & $\begin{array}{l}25 \% \\
10 \% \\
15 \% \\
25 \% \\
15 \% \\
10 \%\end{array}$ & $100 \%$ \\
\hline & & C6 Emissions at construction time & $20 \%$ & $\begin{array}{l}\text { I12 Global warming potential } \\
\text { I13 Total waste }\end{array}$ & $\begin{array}{l}80 \% \\
20 \%\end{array}$ & $100 \%$ \\
\hline & & C6 Emissions for maintenance & $20 \%$ & $\begin{array}{l}\text { I12 Global warming potential } \\
\text { I13 Total waste }\end{array}$ & $\begin{array}{l}80 \% \\
20 \% \\
\end{array}$ & $100 \%$ \\
\hline & & C7 Energy & $20 \%$ & $\begin{array}{l}\text { I14 Embodied energy } \\
\text { I15 Construction energy } \\
\text { I16 Service and maintenance energy }\end{array}$ & $\begin{array}{l}20 \% \\
40 \% \\
40 \%\end{array}$ & $100 \%$ \\
\hline & \multirow{3}{*}{$20 \%$} & & $100 \%$ & & & \\
\hline \multirow[t]{2}{*}{ R3. Social } & & C8 Third parties & $50 \%$ & $\begin{array}{l}\text { I17 Comfort, thermal, air, and among others, noise } \\
\text { I18 Noise pollution, construction } \\
\text { I19 Particles pollution, construction } \\
\text { I20 Traffic disturbances, construction } \\
\text { I18 Noise pollution, maintenance } \\
\text { I19 Particle pollution, maintenance } \\
\text { I20 Traffic disturbances, maintenance }\end{array}$ & $\begin{array}{l}10 \% \\
15 \% \\
15 \% \\
15 \% \\
15 \% \\
15 \% \\
15 \% \\
\end{array}$ & $100 \%$ \\
\hline & & C9 Risks & $50 \%$ & $\begin{array}{l}\text { I21 Health and safety during construction } \\
\text { I22 Health and safety during maintenance } \\
\text { I23 Occupational safety. Risk of disaster } \times \text { cost of life disruption }\end{array}$ & $\begin{array}{l}40 \% \\
40 \% \\
20 \%\end{array}$ & $100 \%$ \\
\hline
\end{tabular}


Table 4. Results of the MIVES application.

\begin{tabular}{|c|c|c|c|c|c|c|c|c|c|}
\hline \multirow[b]{2}{*}{ REQUIREMENT } & \multirow[b]{2}{*}{ INDICATORS } & \multicolumn{4}{|c|}{ Steel Mesh } & \multicolumn{4}{|c|}{ Polyolefin Fibres } \\
\hline & & $\begin{array}{l}\text { Score } \times \\
\text { Rweighs }\end{array}$ & $\begin{array}{c}\text { Score } \times \\
\text { Cweights }\end{array}$ & $\begin{array}{l}\text { Score } \times \\
\text { Iweights }\end{array}$ & $\begin{array}{l}\text { Score } \\
(0-100)\end{array}$ & $\begin{array}{l}\text { Score } \times \\
\text { Rweighs }\end{array}$ & $\begin{array}{c}\text { Score } \times \\
\text { Cweights }\end{array}$ & $\begin{array}{l}\text { Score } \times \\
\text { Iweights }\end{array}$ & $\begin{array}{c}\text { Score } \\
(0-100)\end{array}$ \\
\hline \multirow{5}{*}{ R1. Economic } & I1 Total costs including construction time & \multirow{5}{*}{40.03} & 28.80 & 72.00 & 72 & \multirow{5}{*}{22.47} & 28.67 & 71.67 & 72 \\
\hline & I2 Non quality costs & & 7.20 & 72.00 & 72 & & 4.55 & 45.50 & 46 \\
\hline & I3 Dismantling costs & & 8.00 & 80.00 & 80 & & 3.00 & 30.00 & 30 \\
\hline & I4 Cost of Service, maintenance, energy, change of use & & \multirow{2}{*}{36.05} & 76.80 & 96 & & \multirow{2}{*}{8.73} & 8.48 & 11 \\
\hline & I5 Resilience, risk of disaster $\times$ cost of reconstruction + lack of use & & & 13.33 & 67 & & & 13.33 & 67 \\
\hline \multirow{19}{*}{ R2. Environmental } & I6 Cement & \multirow{19}{*}{13.87} & \multirow{6}{*}{4.65} & 3.00 & 12 & \multirow{19}{*}{8.37} & \multirow{6}{*}{3.27} & 3.00 & 12 \\
\hline & I7 Aggregates & & & 3.17 & 32 & & & 3.17 & 32 \\
\hline & I8 Reinforcement (steel mesh, steel fibres, polyolefin fibres) & & & 9.30 & 62 & & & 2.40 & 16 \\
\hline & I9 Water & & & 4.03 & 16 & & & 4.03 & 16 \\
\hline & I10 Auxiliary Materials & & & 3.75 & 25 & & & 3.75 & 25 \\
\hline & I11 Reused Material & & & 0.00 & 0 & & & 0.00 & 0 \\
\hline & I6 Cement & & \multirow{6}{*}{4.92} & 9.22 & 37 & & \multirow{6}{*}{0.98} & 1.84 & 7 \\
\hline & I7 Aggregates & & & 4.92 & 49 & & & 0.98 & 10 \\
\hline & I8 Reinforcement (steel mesh, steel fibres, polyolefin fibres) & & & 1.55 & 10 & & & 0.31 & 2 \\
\hline & I9 Water & & & 5.76 & 23 & & & 1.15 & 5 \\
\hline & I10 P Auxiliary materials & & & 3.13 & 21 & & & 0.63 & 4 \\
\hline & I11 Reused material & & & 0.00 & 0 & & & 0.00 & 0 \\
\hline & I12 Global warming potential & & \multirow{2}{*}{11.13} & 42.40 & 53 & & \multirow{2}{*}{5.02} & 19.12 & 24 \\
\hline & I13 Total waste & & & 13.25 & 66 & & & 5.98 & 30 \\
\hline & I12 Global warming potential & & \multirow{2}{*}{11.13} & 42.40 & 53 & & \multirow{2}{*}{5.02} & 19.12 & 24 \\
\hline & I13 Total waste & & & 13.25 & 66 & & & 5.98 & 30 \\
\hline & I14 Embodied energy & & \multirow{3}{*}{14.40} & 20.00 & 100 & & \multirow{3}{*}{13.60} & 20.00 & 100 \\
\hline & I15 Construction energy & & & 40.00 & 100 & & & 40.00 & 100 \\
\hline & I16 Service and maintenance energy & & & 12.00 & 30 & & & 8.00 & 20 \\
\hline
\end{tabular}


Table 4. Cont.

\begin{tabular}{|c|c|c|c|c|c|c|c|c|c|}
\hline \multirow[b]{2}{*}{ REQUIREMENT } & \multirow[b]{2}{*}{ INDICATORS } & \multicolumn{4}{|c|}{ Steel Mesh } & \multicolumn{4}{|c|}{ Polyolefin Fibres } \\
\hline & & $\begin{array}{l}\text { Score } \times \\
\text { Rweighs }\end{array}$ & $\begin{array}{l}\text { Score } \times \\
\text { Cweights }\end{array}$ & $\begin{array}{l}\text { Score } \times \\
\text { Iweights }\end{array}$ & $\begin{array}{l}\text { Score } \\
(0-100)\end{array}$ & $\begin{array}{l}\text { Score } \times \\
\text { Rweighs }\end{array}$ & $\begin{array}{l}\text { Score } \times \\
\text { Cweights }\end{array}$ & $\begin{array}{l}\text { Score } \times \\
\text { Iweights }\end{array}$ & $\begin{array}{c}\text { Score } \\
(0-100)\end{array}$ \\
\hline \multirow{11}{*}{ R3. Social } & I17 Comfort, thermal, air, noise, etc. & \multirow{10}{*}{20.00} & \multirow{7}{*}{50.00} & 10.00 & 100 & \multirow{10}{*}{13.20} & \multirow{7}{*}{32.00} & 10.00 & 100 \\
\hline & I18 Noise pollution, construction & & & 15.00 & 100 & & & 15.00 & 100 \\
\hline & I19 Particles pollution, construction & & & 15.00 & 100 & & & 15.00 & 100 \\
\hline & I20 Traffic disturbances, construction & & & 15.00 & 100 & & & 15.00 & 100 \\
\hline & I18 Noise pollution maintenance & & & 15.00 & 100 & & & 3.00 & 20 \\
\hline & I19 Particles pollution, maintenance & & & 15.00 & 100 & & & 3.00 & 20 \\
\hline & I20 Traffic disturbances, maintenance & & & 15.00 & 100 & & & 3.00 & 20 \\
\hline & I21 Health and safety during construction & & \multirow{3}{*}{50.00} & 40.00 & 100 & & \multirow{3}{*}{34.00} & 40.00 & 100 \\
\hline & I22 Health and safety during maintenance & & & 40.00 & 100 & & & 8.00 & 20 \\
\hline & I23 Occupant Safety, risk of disaster $\times$ cost of life disruption & & & 20.00 & 100 & & & 20.00 & 100 \\
\hline & & 74 & & & & 44 & & & \\
\hline
\end{tabular}




\section{Discussion}

The MIVES method has been recently been applied for the sustainable assessment of industrial buildings [23], underground structures [24], hydraulic structures [25], wind towers [26], or sewage systems [27]. This study showed the results of the method when applied to two different solutions that were constructed at the same time. This showed that the method can be applied beyond the decision-making process, in order to analyse the impact of an actual building or constructed element. That is to say, this was an excellent opportunity to verify the applicability of the model.

Table 4 shows the partial and final results of each of the indicators. The final score of the conventional solution for the slab, with steel-mesh reinforced concrete, received a total score of 74 points out of 100 . This production manner can be considered as standard, and the total score shows the solution is accurate for most of the terms. Nevertheless, one of the major drawbacks is the need for continuous maintenance works in order to keep the operational requirements of the structure. This shows how the conventional decision-making procedures in construction projects lacks the consideration of future costs of conservation and sustainable exploitation.

Regarding the final score of the polyolefin fibre-reinforced concrete slab, it showed a significant improvement. The final score was 44 , representing $68 \%$ of the reduction, and considering the three main requirements. If the table is observed, it can be found that the economic requirement shows the most considerable reduction of the score, with a $78 \%$ lower score. Hence, in all probability, this shows that this study was possible, mainly because it was profitable for the contractor. However, it should also be highlighted that reductions of $45 \%$ and $52 \%$ of the requirements in environmental and social issues were achieved, and they should be considered in future works.

The economic indicators showed benefits in the case of the solution with polyolefin fibres, mainly in the non-quality costs that can be remarkably reduced by the use of fibres. In the same sense, dismantling costs with this type of reinforcement as well as maintenance were significantly lower.

The environmental requirements were mainly based on the material consumptions. In such a sense, there were slight differences in the material for construction. However, it should be noted that the type of reinforcement implies reductions on the kilograms of reinforcement and on the GPW of the material used. However, the impact of these reductions is boosted, given the lack of required maintenance needed on the slab built with polyolefin fibres.

Concerning the social criteria, health and safety during production was not considered to have a big impact, although there was a big reduction, if the lack of maintenance in the case of the reinforcement with polyolefin fibres was considered.

Although some further studies might enhance the conclusions, the use of MIVES has been shown to be a powerful tool in order to make the best decision, as a comparative model. It considers the most relevant parts of the works, and supports the final solution. Nonetheless, it is true that further works could enhance the use of this type of multi-criteria decision-making method, based on the value function concept, and the seminars given by experts. That is to say, the development and availability of the enhanced data basis and life-cycle analysis of construction materials and procedures may supply more accurate results. In addition, the continuous use of MIVES could also supply accepted rules for the seminars provided by experts. Moreover, this case study shows how the applicability of those ideas and weights that are accepted as general in reference [22] and EHE-08 [21] meets those that are expected, with reliable results.

\section{Conclusions}

The MIVES approach to the decision-making process has identified the differences between two options that had been constructed. The MIVES considered not only socioeconomic, but also environmental aspects that are not conventionally taken into consideration in the construction field. The assessment of parameters beyond the economic ones have been a key factor in showing the benefits of choosing the reinforcement with polyolefin fibres instead of the conventional steel-mesh. 
The use of a multi-criteria decision-making method based on the value function concept and the seminars provided by experts, such as MIVES, has proved to be a powerful tool in assessing the sustainability of several construction options. The conventional solution for the slab, with steel-mesh reinforced concrete, received a total score of 75 points out of 100, showing that one of the major drawbacks is the need for continuous maintenance works in order to keep the operational requirements of the structure. This point could not be easily be seen by conventional methods.

However, the economic impact was not the only benefit of changing the reinforcing material. The final score of the polyolefin fibre-reinforced concrete slab was 45 , representing $63 \%$ reduction and considering the three main requirements. The economic requirement showed a significant reduction of the score, with a $78 \%$ lower score. The reductions of the requirements in environmental and social issues were $45 \%$ and $52 \%$, respectively. Given that the actual costs and risks could be used in this case study, the use of MIVES highlighted these additional advantages from the use of an alternative solution.

The development and availability of an enhanced data basis and a life-cycle analysis of construction materials and procedures may supply more accurate results. In addition, the continuous use of MIVES could also supply accepted rules for the seminars provided by experts.

This analysis concludes that applying MIVES to various solutions that have already been constructed can help to improve the conventional decision-making processes, highlighting that some advantages of certain solutions must be addressed from a wider point of view. In addition, this case study supplies relevant information for future concrete slab construction, in order to achieve the best solution. As a final note, the MIVES method has shown to be suitable for these analyses, and this contribution may also help to improve future uses of MIVES for choosing the final solution of construction projects.

Author Contributions: All the authors have contributed to the whole development of the manuscript: designing the research, performing the calculations, writing the text, participating in the seminars for MIVES, discussing the results and obtaining the conclusions.

Funding: This research was funded by the Ministry of Economy, Industry and Competitiveness of Spain by means of grant number BIA2016-78742-C2-2-R.

Conflicts of Interest: The authors declare no conflict of interest.

\section{References}

1. Global Concrete Industry Sustainability. Available online: https://www.concrete.org/publications/ internationalconcreteabstractsportal/m/details/id/56323 (accessed on 7 December 2018).

2. World Economic Situation and Prospects 2018. Available online: https:/ /www.un.org/development/desa/ dpad/wp-content/uploads/sites/45/publication/WESP2018_Full_Web-1.pdf (accessed on 7 December 2018).

3. Rashid, K.; Razzaq, A.; Ahmad, M.; Rashid, T.; Tariq, S. Experimental and analytical selection of sustainable recycled concrete with ceramic waste aggregate. Constr. Build. Mater. 2017, 154, 829-840. [CrossRef]

4. Tekin, I.; Durgun, M.Y.; Gencel, O.; Bilir, T.; Brostow, W.; Lobland, H.E.H. Concretes with synthetic aggregates for sustainability. Constr. Build. Mater. Vol. 2017, 133, 425-432. [CrossRef]

5. McGinnis, M.J.; Davis, M.; Rosa, A.D.L.; Weldon, B.D.; Kurama, Y.C. Strength and stiffness of concrete with recycled concrete aggregates. Constr. Build. Mater. 2017, 154, 258-269. [CrossRef]

6. Manzi, S.; Mazzotti, C.; Bignozzi, M.C. Self-compacting concrete with recycled concrete aggregate: Study of the long-term properties. Constr. Build. Mater. 2017, 157, 582-590. [CrossRef]

7. Amario, M.; Rangel, C.S.; Pepe, M.; Dias, R.; Filho, T. Optimization of normal and high strength recycled aggregate concrete mixtures by using packing model. Cem. Concr. Compos. 2017, 84, 83-92. [CrossRef]

8. Ghorbel, E.; Wardeh, G. Influence of recycled coarse aggregates incorporation on the fracture properties of concrete. Constr. Build. Mater. 2017, 154, 51-60. [CrossRef]

9. Wijayasundara, M.; Mendis, P.; Crawford, R.H. Methodology for the integrated assessment on the use of recycled concrete aggregate replacing natural aggregate in structural concrete. J. Clean. Prod. Vol. 2017, 166, 321-334. [CrossRef] 
10. Evangelista, L.; De Brito, J. Concrete with fine recycled aggregates: A review. Eur. J. Environ. Civ. Eng. 2014, 18, 129-172. [CrossRef]

11. Colangelo, F.; Cioffi, R. Mechanical properties and durability of mortar containing fine fraction of demolition wastes produced by selective demolition in South Italy. Compos. Part B Eng. 2017, 115, 43-50. [CrossRef]

12. Colangelo, F.; Messina, F.; Di Palma, L.; Cioffi, R. Recycling of non-metallic automotive shredder residues and coal fly-ash in cold-bonded aggregates for sustainable concrete. Compos. Part B Eng. 2017, 116, 46-52. [CrossRef]

13. Colangelo, F.; Cioffi, R.; Liguori, B.; Iucolano, F. Recycled polyolefins waste as aggregates for lightweight concrete. Compos. Part B Eng. 2016, 106, 234-241. [CrossRef]

14. Sadeghi-Nik, A.; Berenjian, J.; Bahari, M.A.; Safaei, A.S.; Dehestani, M. Modification of microstructure and mechanical properties of cement by nanoparticles through a sustainable development approach. Constr. Build. Mater. 2017, 155, 880-891. [CrossRef]

15. Aydin, E.; Arel, H.Ş. Characterization of high-volume fly-ash cement pastes for sustainable construction applications. Constr. Build. Mater. 2017, 157, 96-107. [CrossRef]

16. Islam, G.S.; Rahman, M.; Kazi, N. Waste glass powder as partial replacement of cement for sustainable concrete practice. Int. J. Sustain. Built Environ. 2017, 6, 37-44. [CrossRef]

17. Hájek, P.; Fiala, C.; Kynčlová, M. Life cycle assessments of concrete structures-a step towards environmental savings. Struct. Concr. 2011, 12, 13-22. [CrossRef]

18. Our Common Future (The Brundtland Report), World Commission on Environment and Development. Available online: http:/ / www.un-documents.net/wced-ocf.htm (accessed on 7 December 2018).

19. Bribián, I.Z.; Usón, A.A.; Scarpellini, S. Life cycle assessment in buildings: State-of-the-art and simplified LCA methodology as a complement for building certification. Build. Environ. 2009, 44, 2510-2520. [CrossRef]

20. Bribián, I.Z.; Capilla, A.V.; Usón, A.A. Life cycle assessment of building materials: Comparative analysis of energy and environmental impacts and evaluation of the eco-efficiency improvement potential. Build. Environ. 2011, 46, 1133-1140. [CrossRef]

21. EHE-08. Spanish Structural Concrete Code; Spanish Minister of Public Works: Madrid, Spain, 2008.

22. Pons, O.; de la Fuente, A.; Aguado, A. The use of MIVES as a sustainability assessment MCDM method for architecture and civil engineering applications. Sustainability 2016, 8, 460. [CrossRef]

23. Lombera, J.T.S.J.; Rojo, J.C. Industrial building design stage based on a system approach to their environmental sustainability. Constr. Build. Mater. 2010, 24, 438-447. [CrossRef]

24. Ormazabal, G.; Viñolas, B.; Aguado, A. Enhancing value in crucial decisions: Line 9 of the Barcelona subway. J. Manag. Eng. 2008, 24, 265-272. [CrossRef]

25. Pardo-Bosch, F.; Aguado, A. Investment priorities for the management of hydraulic structures. Struct. Infrastruct. Eng. 2015, 11, 1338-1351. [CrossRef]

26. De la Fuente, A.; Armengou, J.; Pons, O.; Aguado, A. Multi-criteria decision-making model for assessing the sustainability index of wind-turbine support systems: Application to a new precast concrete alternative. J. Civ. Eng. Manag. 2017, 23, 194-203. [CrossRef]

27. De la Fuente, A.; Pons, O.; Josa, A.; Aguado, A. Multi-Criteria Decision Making in the sustainability assessment of sewerage pipe systems. J. Clean. Prod. 2016, 112, 4762-4770. [CrossRef]

(C) 2018 by the authors. Licensee MDPI, Basel, Switzerland. This article is an open access article distributed under the terms and conditions of the Creative Commons Attribution (CC BY) license (http:/ / creativecommons.org/licenses/by/4.0/). 